\title{
Experiences of (Dis)Unity: Students' Negotiation of Ethnic and National Identities in Botswana Schools
}

\section{Citation}

Mulimbi, Bethany and Sarah Dryden\#Peterson. 2019. Experiences of (Dis)Unity: Students' Negotiation of Ethnic and National Identities in Botswana Schools. Anthropology \& Education Quarterly.

\section{Published Version}

10.1111/aeq. 12312

\section{Permanent link}

http://nrs.harvard.edu/urn-3:HUL.InstRepos:41343917

\section{Terms of Use}

This article was downloaded from Harvard University's DASH repository, and is made available under the terms and conditions applicable to Open Access Policy Articles, as set forth at http:// nrs.harvard.edu/urn-3:HUL.InstRepos:dash.current.terms-of-use\#OAP

\section{Share Your Story}

The Harvard community has made this article openly available.

Please share how this access benefits you. Submit a story.

\section{Accessibility}




\title{
Experiences of (Dis)Unity: Students' negotiation of ethnic and national identities in Botswana schools
}

\author{
Bethany Mulimbi \\ Harvard Graduate School of Education and Botswana Educational Research Association \\ Sarah Dryden-Peterson \\ Harvard Graduate School of Education
}

Corresponding Author:

Sarah Dryden-Peterson

Harvard Graduate School of Education

6 Appian Way

Gutman Library 457

Cambridge, MA 02138 USA

Tel: 617-495-8162/ 617-435-2344

Email: sarah_dryden-peterson@gse.harvard.edu

\section{Acknowledgements}

We express our thanks to students, teachers, administrators, staff, and community members who welcomed us into their schools and communities; colleagues at the University of Botswana, especially Nkobi Owen Pansiri, Lydia Nyati-Saleshando, and Kelone Khudu-Peterson; research assistants at each site: Moyagabo, Mosenodi, Bopelo, and Kelebogile; and to Meira Levinson, Paola Uccelli, Elizabeth Adelman, Vidur Chopra, and the Mowana Lab for feedback on earlier drafts.

\section{Funding}

This work was supported by the Weatherhead Center for International Affairs at Harvard University; a Research Enabling Grant from Harvard University; the Fulbright program of the United States Department of State; a Sinclair Kennedy Traveling Fellowship and a Dissertation Completion Fellowship from Harvard University; and National Academy of Education/Spencer Dissertation Fellowship and Postdoctoral Fellowship.

\section{Research Ethics}

All research drawn upon in this essay was approved by the Committee on the Use of Human Subjects at Harvard University and the Botswana Ministry of Education and Skills Development. All participants were aware of our roles as academic researchers and provided with an information sheet about the research, its potential risks and benefits, and their rights within the research; adults gave their written consent for participation and children gave their assent.

\section{Disclosure Statement}

The authors hold no financial interest or benefit arising from the direct applications of this research. 


\section{Author Bios}

Bethany Mulimbi is a Postdoctoral Fellow with the Botswana Educational Research Association. Her research focuses on the interplay between how formal education systems, individual schools, and teachers address the needs of students of diverse cultural and linguistic backgrounds, particularly in Southern Africa (bethany_mulimbi@mail.harvard.edu)

Sarah Dryden-Peterson is an Associate Professor at the Harvard Graduate School of Education. Her research focuses on the connections between education and community development, specifically the role that education plays in building peaceful and participatory societies (sarah_dryden-peterson@gse.harvard.edu) 


\section{Experiences of (Dis)Unity:}

\section{Students' negotiation of ethnic and national identities in Botswana schools}

Botswana has been celebrated as an example of enduring peace and democracy since gaining independence from Great Britain 50 years ago (Dalley, et al. 2013). Botswana's case is particularly striking because many of its close regional neighbors have struggled to control "ethnic cleavages" (Smith 1991:119) that frequently erupt into internal armed conflict. Botswana's leaders recognized that their nation-state faced the same dilemma as other multiethnic states in Africa: how to manage ethnic diversity while promoting a sense of national unity (Coe 2005; Lerch, et al. 2017; Vail 1989). Over time, Botswana's leadership has gradually changed its model for building unity. In the first three decades after independence in 1966, Botswana followed a model common across the African continent (e.g., Vail 1989): explicitly crafting a unified identity in the service of postcolonial nationbuilding and national development. In Botswana, this process "to discipline difference in the interest of preserving the nation" (Ríos-Rojas 2014:3) involved promoting assimilation of ethnic identities to a superordinate national identity constructed around culture and language of the political and economically dominant Tswana ethnic groups (Author $2 \&$ Author 1 2017).

Over the most recent two decades, as individual and group advocacy to recognize minority ethnic groups has grown, the government has begun introducing multicultural discourse into national planning (Author $2 \&$ Author 1 2017), including that "[t]he education system will recognise, support and strengthen Botswana's wealth of different languages and cultural traditions” (Presidential Task Group for a Long-Term Vision for Botswana 1997:5). Yet despite this public rhetoric indicating a shift from assimilation to multiculturalism, recognition of ethnic identity in Botswana's education policies and in the content of teaching 
and learning in schools remains conspicuously absent (Jotia and Pansiri 2013; Author 1 \& Author 2 2017; Author 1 \& Author 2 2018; Nyati-Saleshando 2011).

The embrace of multiculturalism in Botswana, as elsewhere in Africa, has been tentative. As Vail noted, reflecting on widespread assimilationist tendencies in postcolonial nation-states, "for almost every observer nationalism seemed progressive and laudable, while ethnicity - or, as it was usually termed, 'tribalism' - was retrogressive and divisive” (Vail 1989:2). Indeed, conflict over recognition of ethnic and linguistic diversity has often been violent (Davies 2011; Davis 2015; King 2014). Nation-building, particularly where the threat of conflict is perceived to be high, tends to emphasize national unity and de-emphasize ethnic identification (Freedman, et al. 2008; King 2014; Paulson 2015; Teeger 2015). Public schools are key institutions for this socialization of subjects into national citizens (e.g., Boli 1989; Coe 2005; Green 1990; Uslaner and Rothstein 2012; Weber 1976), and schools have acted as a particularly powerful state intervention into individuals' subjectivity in Botswana (Gulbrandsen 2012). Botswana has actively tried to mitigate possible intergroup conflict, most particularly through identity construction within the education system (Author $2 \&$ Author 1 2017; Author 1 \& Author 2 2018).

Within the context of conflicting messages about the role of ethnic identity within Botswana's national identity, this article considers how adolescents in a key developmental stage of identity construction understand and enact their ethnic and national identities, in public and in private, focusing on the disparate experiences of two junior secondary school students. We examine to what extent students of majority and minority ethnic backgrounds experience the national identity constructed in their schools as inclusive of their ethnic groups, and in what ways, for what reasons, and in what spaces they choose to enact their national and ethnic identities. To our knowledge, it is the first study to examine these questions. 
To understand students' experiences of national identity as inclusive or exclusive of their ethnic identities, we first present portraits of two adolescent students (LawrenceLightfoot and Davis 1997), whom we grew to know during a larger ethnographic study on national identity construction, based in their schools in 2015-2016. These two students - of whom one identified with a majority ethnic group and one identified with a minority ethnic background - were both exceptionally successful in their schools in terms of academic achievement and recognized leadership skills. We examine their experiences and understandings of developing and displaying ethnic and national identities in different spheres of their lives, considering how their ethnic and national identities intersect with other social categories important to these individuals, such as region, home language, class, and school performance. We then discuss how structures, curricular content, and peer relationships in their junior secondary schools shaped their identity development and their enactments of national and ethnic identity.

While both students valued their national identity as a path toward a future good life including higher levels of education and employment - enacting this national identity required only the minority student to sacrifice other desired "goods," including connections to family heritage and recognition. Given that these students were exceptional in their school success, a more typical experience for students of ethnic minority backgrounds may well be that the education and employment values of their national identity were inaccessible, undermining for minority students the salience of the national identity conveyed in schools.

\section{Managing National and Ethnic Identities}

Although the name of the country indicates that Botswana is the home of the Tswana people, there are many self-identified ethnic groups within the national borders. In fact, Botswana has been largely overlooked in studies of ethnicity in Africa or used as a 
comparative case to hold ethnicity constant, with the false assumption that "the nation state and ethnicity are largely coterminous" (Vail 1989:18). Policy-makers and minority rights advocates use widely varying population estimates of ethnic groups, characterizing Botswana as ethnically homogenous or ethnically diverse, with claims ranging from 18 percent majority Tswana (Nyati-Ramahobo 2006a; Nyati-Saleshando 2011) to 80 percent majority Tswana (Republic of Botswana 1977). The Afrobarometer survey is the only nationally representative data that includes self-reports of ethnicity. In the three years that include data on ethnicity $(2005,2008,2012)$, just over half of respondents identify as Tswana, and slightly under half identify as one of 21 other ethnic groups (Author $2 \&$ Author 1 2017). The Constitution recognizes eight "major tribes" who are sometimes considered separate ethnic groups but share the common (national) language, Setswana, and tend to be distinguished from one another by family lines and historical territory (Nyati-Ramahobo 2006b; Pansiri 2012; Republic of Botswana 2000); as is typical in English, we term these groups Tswana. Ethnic minority groups, who are not named in the Constitution, are diverse in terms of culture and language, historical migrations into modern-day Botswana, and political and economic standing, yet all have long experienced geographical, political, or economic marginalization (Gapa 2017; Gulbrandsen 2012; Werbner 2004). This ethnic composition, with one group numerically dominant and numerous other ethnic groups, combined with economic and social factors, created a strong possibility of violent conflict in post-Independence Botswana (Author 2 \& Author 12017 ).

King's (2014) analysis of links between education and conflict help us to identify two processes that Botswana's state leadership has actively tried to manage since independence: horizontal inequalities and social identity development. First, building on Ted Gurr's work (1970), King defines horizontal inequalities as "severe social, political, and/or economic inequalities" (2014: 23) perceived to exist between groups. Botswana's government has 
worked unceasingly to avoid horizontal inequalities between ethnic groups through redistribution, for example by rapidly expanding access to schools of similar quality throughout the country (Gapa 2017). The government's efforts to equalize access to and quality of public schools have paid off; thus far Botswana has avoided widespread perceptions that inequalities in educational access and outcomes exist between ethnic groups, rather than simply between individuals (Author 2 \& Author 1 2017). This public perception that inequalities between individual students are more pertinent than those between ethnic groups may find support in the fact that within-school variation in exam results is larger than between-school variation in Botswana (Marope 1996); but it may also be perpetuated by the fact that the Ministry of Education does not collect data on students' ethnicity, which serves to hide disparities in school achievement by ethnicity (Jotia and Pansiri 2013).

Second, Botswana's leadership has intentionally sought to construct an inclusive national identity in such a way as to manage possible divisions of ethnic identification, so that these differences do not undermine national stability. Our ethnographic inquiry into ethnic and national identification is informed by seminal work in psychology on social identity theory, or the tendency to categorize individuals as ingroup or outgroup members (Tajfel and Turner 1979) and for individuals to have more positive affect towards, be more willing to help, and retain more detailed information about ingroup members than outgroup members (Dovidio, et al. 2003). Empirically, ethnicity is a key line of demarcation between ingroup and outgroup members in Africa (Michalopoulos and Papaioannou 2015; Robinson 2009; Vail 1989) and is more predictive of conflict than religion or regional categorizations (Østby and Urdal 2010).

Yet social categorization and identity, including ethnicity, is socially constructed and thus malleable (Gaertner and Dovidio 2000). Through institutions such as schools, state leadership actively constructs certain types of national identity to include or exclude various 
sub-groups (Kymlicka and Norman 2000). Ethnic groups and individuals who identify with those included or excluded groups construct ethnic identity variably, according to the power relationships in which they are embedded and what they stand to gain by constructing ethnic identity in particular ways (Cornell and Hartmann 1998). Local communities may undercut state efforts to appropriate culture into a national identity by incorporating their own understandings and practices of cultural elements of identity (Coe 2005). Many postcolonial nation-building efforts, which like Botswana sought to promote peace and stability, focused on models for creating inclusive identities - social identities that emphasize similarities and tolerance rather than rigid binaries. The drastic change of power relations, brought about by Independence, provided the opportunity to do so.

\section{Constructing Inclusive Identities through Education}

Since Botswana's Independence, the central government has sought to construct such an inclusive national identity through its public schools. The state exerts an especially strong authority over individuals' subjectivity in Botswana through the pervasive reach of government services into every corner of the country (Gapa 2017; Gulbrandsen 2012), including the provision of near-universal access to a 10-year education (UNESCO 2011). Schools bring to every community primarily non-local teachers, economically dependent on the government (Gulbrandsen 2012), who transmit a nationalized curriculum that they follow with great fidelity (Tabulawa 2009). The formal curriculum conveys the benevolence of the state, through assurances of equality for all citizens and redistribution of resources for national development (Author $1 \&$ Author 2 2018). At school, students hear through the curriculum and see through the example of their teachers that mastery of this nationalized curriculum represents a path - accessible to all - to paying jobs and inclusion in the modern nation-state (Gulbrandsen 2012). 
The education system in Botswana has taken a particular approach to creating an inclusive national identity for all students. This approach, adopted through the first education policy, Education for Kagisano, and unchanged in the current policy, the Revised National Policy on Education, promotes national identity as more important than ethnic identity. Further, key aspects of the national identity taught in schools are rooted in the majority ethnic group, connected to Tswana cultural practices and the Setswana language (Author $2 \&$ Author 1 2017), which Independence and post-Independence era state leaders have actively worked to consolidate into one self-identifying ethnic group, rather than eight disparate tribes (Gapa 2017; Janson and Tsonope 1991). School curriculum encourages toleration for different ethnic groups, accepting that differences in arts, languages, and lifestyles exist between them and should be treated as private matters rather than publicly recognizing minority group experiences and perspectives (Gutmann 1999; Author 1 \& Author 2 2018). As such, Botswana has adopted a recategorization approach toward inclusive identities (Gaertner and Dovidio 2000). This approach attempts to eliminate ethnic divisions by "promot[ing] the creation of a [national] group identity at a higher level than existing [ethnic] groups" (King 2014:30).

Yet, numerous empirical studies have suggested that this recategorization approach, which encourages homogeneity in place of long-standing self-defining sub-groups, may not be sustainable or effective at avoiding inter-group conflict in the long-term, due to the continuing salience of ethnic identity and a tendency for recategorization to involve assimilation to a dominant group's identity (Dovidio, et al. 2010; King 2014). Indeed, ethnic minority advocacy has grown in Botswana over the past two decades, and a Presidential Inquiry into certain sections of the Constitution concluded that, due to widespread public perceptions of discrimination against minority ethnic groups: “...the long-term stability of this country, and in particular, the sustainability of its unity, could not be guaranteed" 
(Republic of Botswana 2000:9). As of this writing, the sections of the Constitution found to be discriminatory are unchanged.

Alternative approaches to building inclusive identities are centered in pluralism, acknowledging the continuing existence and salience of sub-groups, such as ethnic groups and encouraging positive, cooperative relationships between groups, in the interest of reaching common goals. This model emphasizes the distinctiveness of original sub-groups and has been the focus of post-apartheid state policymaking in neighboring South Africa, for example (Ross 2007). Yet this model has been explicitly less appealing to leaders in Botswana, who have sought to minimize the salience of ethnic identification, fearing what former President Quett Masire (in office 1980-1998) described as "letting the tiger [of tribalism] loose" (Werbner 2002). Between pluralism and assimilation lies what some have termed a "dual-identity model," in which a superordinate (national) identity and a sub-group (ethnic) identity coexist (Dovidio, et al. 2010). These theoretical models of inclusive national identities are shown in Figure 1.

[Figure 1 about here]

The assimilationist identities of a recategorization approach tend to be more salient for majority group members, while those who identify most strongly with minority groups tend to prefer dual-identity representations (van Oudenhoven, et al. 1998). Indeed, individuals belong to multiple social groups concurrently, and overlapping social identities interact to create myriad subjective experiences within apparently bounded sub-groups (Collins 2012; Sumi, et al. 2013). While ethnic background is an important social category in Botswana that is embedded in longstanding power structures, gender, social class, language(s) proficiency, school performance, and myriad other factors mediate one's subjective experience of ethnicity. 
The intersectionality of identity means that ways of enacting one aspect of a social identity may conflict or intersect with another aspect, especially as connected to awareness of membership in a group, the value placed on that membership, and emotional investment in that membership (Ashcraft, et al. 2017; Han 2014; Paniagua 2017; Tajfel 1982). For example, individuals who face discrimination because of their minority background may choose not to speak their home language if it signals their minority group membership to others (Shin 2013). Yet individuals who have had the opportunity to develop proficiency in their home language alongside a dominant language are more likely to embrace dual identities, such as a national and ethnic identity (Lee and Suarez 2009). We posit that the Tswana-based national identity conveyed through the recategorization model in Botswana's schools may cause conflict between ethnic and national identification for minority students, but not for Tswana students. Yet students of minority ethnic backgrounds may value their national identity similarly to Tswana students if they perceive their rights, access to institutions, and mobility to be equitable.

A recent body of literature on ethnicity in Africa considers "national identity salience" and "ethnic identity salience" fixed variables for predicting conflict, corruption, and inequality (Michalopoulos and Papaioannou 2015; Robinson 2009). In this article, we seek an understanding of the processes and choices involved in enacting national and ethnic identities at particular times and in particular contexts. We explore how students of majority and minority ethnic backgrounds in Botswana learn how to identify along national or ethnic lines, the ramifications of enacting certain identities, and how they are identified by others. Through in-depth presentations of data from two students, we identify what signaled membership in ethnic versus national communities to them and to others, what value and emotional investment they placed on each identity, and how the structures, content, and relationships in their schools affected their understandings and decisions of how to enact their 
national and ethnic identities. Our inquiry allows us to theorize the meaning of the “controlling processes" (Nader 1997) of school-based postcolonial identity construction visà-vis young people's identification with and participation in the nation-state.

\section{Ethnographic Context, Methodology, and Researcher Positionality}

We focus on processes of identity construction that occur through structures, curricular content, and peer- and student-teacher relationships in schools, the context in which adolescents in Botswana spend the majority of their time outside of home. The structures of schooling include policies and processes that affect students' access to schooling, such as school fees, school buildings and qualified teachers in one's community, segregated versus integrated schools, or languages of instruction that students can comprehend. The curricular content of schooling includes formal curriculum, which transmits authorized knowledge from the state, and day-to-day pedagogical practices, through which teachers transmit values and dispositions through their words and actions (Apple 2004; Selander 1990). It is critical to examine students' relationships with teachers and peers at school in addition to the content and structures of schooling. Students' need for belonging is a fundamental human need (Osterman 2000), and the need for connectedness to others through relationships - is strongest during early adolescence (Chapman, et al. 2013), the age of most junior secondary school students in Botswana. Students may enact aspects of their ethnic or national identity not simply based on curricular and structural expectations in their schools, but also out of desire to establish meaningful relationships within or outside of their ethnic group at school.

We collected the data for this article in the context of comparative case studies (Yin 2014) of four junior secondary schools in regions of Botswana that vary in the ethnic composition of their student bodies and surrounding communities. The study investigated 
how national identity was constructed in Botswana's public junior secondary schools, how the construction of national identity varied across and within the four school contexts, and how students and teachers from different ethnic groups made sense of their roles as national citizens. In the first phase of the study, we analyzed education policy documents, school curricula, and textbooks, and the second author conducted a set of key informant interviews to understand historical and contemporary decision-making related to the construction of national identity in Botswana schools. In the second phase of the study, the first author spent six weeks at each school between February-September 2015, accompanied at one school by the second author, conducting participant observation across contexts in each school (assemblies, informal interactions at break times, lessons, extracurricular activities, staff and PTA meetings), as well as interviews with teachers and administrators and focus groups and interviews with students. In the third phase of research, both authors returned to three of the four schools for three to six weeks in late 2015 and early 2016 to run action research projects with 10 to 15 students at each school who chose to participate in a research club. Data from the school case studies serve to contextualize the student experiences we analyze in detail here, as well as to inform themes we discuss as pertinent to the many students involved in the study.

Our positions as outsiders to the communities and schools in which we carried out this research, as well as being non-natives of Botswana shaped our data collection and analysis. At times, school staff were reluctant to share their personal views on ethnic relations at large and within the schools. Yet they elaborated on the charged nature of conversations around ethnicity and fears of "tribalism" in more general terms, taking care to explain because they did not assume our prior understanding of these issues. Students were less guarded and described particular encounters between individuals or groups that they identified as relevant to ethnicity or relations among ethnic groups. Conversations between students in the research 
groups, as they discussed data they collected from their peers and family members, yielded the richest insights into inter-ethnic relations and students' construction of identity categories. Our inability to understand the many local languages of our research sites meant that we could not fully interpret most student-to-student informal interactions that we observed firsthand. We employed local youth as research assistants, to translate in school contexts where English was not the main mode of communication and for the initial student focus groups. Yet we found that students were more at ease and willing to explain points they made in local languages when they interpreted for one another, as during the research clubs. Overall, our status as outsiders to Botswana and the local communities where we carried out research seemed to simultaneously enhance the reach of data collection - by allowing students to discuss issues of inter-ethnic relations that were usually off-limits when they were in the presence of teachers or community members who were their elders - and limit the depth to which some students were able to express their perspectives - by requiring that the majority of our conversations take place in English or through a translator.

The students we present as cases here were drawn from two of the four case study schools in the larger study - one in an important village of a Tswana majority ethnic group, and the other in the remote and sparsely populated Northwest district, home to several of the smallest ethnic groups in Botswana. We grew to know each student initially through the focus groups and individual interviews in the second phase of the study (the initial six-weeks at each school). Focus group questions aimed to generate discussion between students about expectations of "good citizenship" in Botswana, sources of pride and shame in their national identity, and Botswana's progress on national goals related to unity and recognition of ethnic diversity. Individual student interviews lasted approximately one hour and solicited information on the students' home background and early school experiences, structures, curricular content, and interactions in their current schools, and their reflections on the 
meaning of citizenship, ethnic and national identity, and school experiences. Both students sought out the first author for informal conversations and academic advice during this time, due to their curiosity about the research process and greater confidence speaking English than many of their peers.

When we returned to their schools, these two students were among the first to volunteer for the research club. This club reinforced students' knowledge of the research process, as taught in their social studies classes, and asked them to apply the process in a follow-up study of themes that emerged from the first two phases of the study. Students in the club discussed their perspectives on relations between ethnic groups and the meaning of national identity at their school and in the community; developed and administered a survey for their peers at school, to quantify other students' feelings related to these issues; and deepened their understanding of the survey results through interviews with fellow students and community members, before preparing posters to publicly display their findings at their school. From the students' research club participation, we draw on written fieldnotes, digitally recorded and transcribed club discussions, and one-on-one interviews conducted by the students with family members. In all of these data sources, the students reflected on national identity and ethnic group relations. This close work with students in analysis of the data from the first and second phases of research and in co-construction of the third phase of research served as an additional way for us to interrogate our positions as outsiders and to further refine our analysis.

Looking across the range of interactions we had with each student, we identified themes related to a) students' articulation of their membership in ethnic and national groups, b) the value and emotional attachment they described from such group memberships, c) relationships that influenced their knowledge of or emotional attachment to the national or 
ethnic group, and d) how characteristics and dispositions of the students as well as the content and structures of their schools interacted with their sense of national and ethnic identity. We also examined patterns we observed in these students' social identity development in comparison to patterns we had identified among their peers.

\section{The Promise of National Identity: Access to Education and Employment}

The two students presented in detail here - Onalenna and Thato - were exceptional on several dimensions: their efforts and abilities put them near the top of their class in academic achievement; they had vast knowledge of current events and historical facts learned outside of school, compared to most of their peers; and they were unusually reflective in discussions of their identities, both national and ethnic. As such, they represent the upper limits of awareness and resources that students may draw from when negotiating ethnic and national identities within the confines of public junior secondary schools in Botswana. Their experiences and reflections illuminate not what is typical, but what is possible for those students most adept at enacting and reaping promised rewards of multiple social identities. Their exceptionality allows us to more clearly demonstrate the interplay between how nonschool influences and school structures, curricular content, and relationships can shape social identity development, with the goal of identifying themes relevant to students of minority and majority ethnic groups in Botswana more broadly.

While Onalenna and Thato were similar in their exceptional school achievement, leadership, and reflectiveness, their identification with majority and minority ethnic groups, respectively, led to very different realities in the identity-based sacrifices and individual efforts they had to make in order to access the value of a national identity. Onalenna, who identified as a member of one of the predominant Tswana groups, found the Setswana language of instruction and Tswana-based history and culture in the national curriculum accessible and natural. Thato, who identified with one of the smallest ethnic groups, the 
Wayeyi, found that he had to learn Setswana without second-language supports, leave his family home to attend school, and master a curriculum devoid of Wayeyi cultural and historical understandings. Yet both students' school success and social capital in the form of family members participating in gainful employment mediated the value that they attached to ethnic and national identities, differentiating their experiences from those of many fellow students who identified with diverse ethnic groups, both majority and minority.

We first present Onalenna and Thato's experiences in the form of narrative portraits. We have chosen this form, and the initial narrow focus on each individual, in order to provide a holistic understanding of each student as a unique individual situated within a particular family, community, and school context. We then turn to discussion of similar and contrasting patterns in their experiences in more detail.

\section{Onalenna: “I do belong”}

"I've never seen anyone being that disadvantaged," Onalenna said the first time we spoke with her, as her focus group discussed language of instruction policies in Botswana's schools. We had asked for the group's reactions to a national goal that no student should be disadvantaged in the education system because they spoke a home language that differed from the two languages of instruction - English and Setswana. Scholars and minority rights advocates outside of schools have contended that these language of instruction policies account for large regional discrepancies in exam results (Nyati-Saleshando 2011; Pansiri 2008). Onalenna likely never had witnessed minority language speakers be disadvantaged in her schools, in this longstanding village of the Bagkatla, a major Tswana group. Yet Onalenna was not the sort to limit her understanding to her immediate environment and interactions, but to read widely and reflect. As she later said, “At home I'm told, 'If you are asked a question, answer it like you've been thinking for a long time.'” 
Onalenna was a studious, thoughtful young woman. Whenever we observed her classroom, we found her studying at her desk, midway up the room, next to a window. Even if there was no teacher present - an opportunity many of her classmates took to goof off inside the classroom or rough-house on the dusty grounds between buildings, Onalenna would be working quietly with one or two other girls sitting near her. When a teacher was in the class, Onalenna eagerly participated and led group work, earning recognition and praise from her teachers. Her family was also well-recognized at the school, where her father was active on the PTA, and in this village, where her ancestors were close to the paramount chiefs. Onalenna also saw her ethnic group, the Bakgatla, explicitly recognized in schools, saying,

Knowing that the school is named after the district and the chief, it shows us... Not offending the people who come from other ethnic groups, they know that this is a school from Kgatleng [Bakgatla district] ... So that gives the students a sense of knowing that, "I belong in Kgatleng." Even my school shows me that I do belong in a certain ethnic group.

The largest ethnic group in Onalenna's school was, indeed, Bakgatla, at just over half of the student body. Still, students in our research club, including Onalenna, were surprised to learn that there were students from at least 12 other ethnic groups at the school, and that 14 percent of the student body was non-Tswana. Students of minority ethnic groups at Onalenna's school told us in private that they quickly adapted to Bakgatla ways of speaking, and most avoided openly displaying their ethnic backgrounds at school, for fear of being teased. Although Onalenna understood that her familiarity with the Setswana language of instruction as her home language might provide certain advantages over "people who come from other ethnic groups," she believed that these advantages were less relevant in her region of the country because, students are "not using the [minority] language down here." While in private spaces, other students from Onalenna's school used these minority languages, in public spaces in the community and at school, Onalenna did not hear them. 
Onalenna was comfortable at school, not just because she felt her ethnic group belonged there, but also for the opportunities it provided for her future. From a young age, she said, "I knew that I have to go to school to become like my mom or dad, to be educated." Citing rising unemployment, she understood from school and home that even successfully completing school would not necessarily lead to a career. As she explained,

At school they're telling us, if you're not serious here at junior [secondary school], you know that your aunt or your cousin has a degree, and she or he is sitting at home. He's not working. She's not working. What about you, in the next five years or ten years, where will you be?

Yet this awareness simply led to Onalenna's greater determination to use her education wisely. With her parents' guidance, she was considering which courses she should take based on "where people are really needed."

Onalenna's material resources from home exceeded those of most students in her class, and her family channeled them towards increasing their knowledge of current events. She described how her family would spend their evenings each on their own laptop, "browsing the internet, watching something," and sharing what they had learned with one another. From these family interactions around media, Onalenna had learned about Botswana's water crisis and a promising pipeline to address it, the need to diversify Botswana's economy as the diamond reserves dwindled, and legal battles over nomadic KhoiSan groups' land rights, among other issues not covered in her school curriculum.

Onalenna's family resources also extended her knowledge of Botswana's ethnic diversity. Despite their long roots in her home village, Onalenna's family defied easy categorization along ethnic lines, causing her to wonder, "After being a Mokgatla, what am I? I'm still trying to figure out what I am." She spoke Setswana with most of her relatives but had spoken Sesotho ${ }^{1}$ with her mother at an early age and now conversed predominantly in English at home. Her father had a British grandfather and had travelled extensively; her mother had lived with relatives in Lesotho, where she learned Sesotho; her aunt was marrying 
a man from the Kalanga minority ethnic group; and her great uncle had married a minority Herero woman. She had gained - and actively sought - deep knowledge about each of these groups through interactions with her relatives. Such knowledge was not expected by, or available within, the curricular content of her school.

Yet, Onalenna was content with how her school approached ethnic pluralism in relation to Botswana's national identity. Along the lines of the recategorization approach, she appreciated the priority given to national identity over ethnic identity in the interests of equality across ethnic groups. She described what she had learned in social studies as follows: "When it comes to nationality or the nation, we say all people are equal.... [I]f we would say that ethnic identity is more important than the national identity, some people would be left behind." Her school's promotion of toleration for different ethnic groups also fit with messages from her church, where she said, "We're taught if you don't tolerate that other person, then you don't tolerate God."

Yet when we asked her in an interview to imagine how she might feel about school if she came from an ethnic minority group and spoke a minority language at home, she spoke at length, finally concluding:

And also in school, I can't understand anything the teachers say, so there's no reason for me to be in school. There's no reason for me to be here at all. I would feel like I'm not accepted, I'm not tolerated here.

We noted from Onalenna's apparent ease with reflecting on this scenario that she must have contemplated such ideas before. Yet when we asked her "Have you thought about this before?" she replied, "Never."

\section{Thato: "They look down on you"}

Not a day went by when Thato did not think about who he was in connection to his school and his country. His school was in the remote Northwest District of Botswana, where 
the sands of the Kalahari to the west must constantly be swept back from the concrete walks, and there is little sign that the lifeline of the region, the Okavango River Delta, lies just a few kilometers to the east. Tall, with a wide smile, he proudly displayed a badge that marked him as a student leader on the lapel of his impeccably clean but worn school jacket. Thato seemed to have a foot in multiple worlds. He was deeply rooted in his Wayeyi ethnic heritage while embracing an education that drew him toward national and global communities and away from those roots - both geographically and culturally.

The Wayeyi, the ethnic group that calls the interior of the Okavango Delta home, is one of the smallest ethnic groups in Botswana. They had limited contact with Tswana groups - who are historically concentrated in the southeast of Botswana - until one Tswana group, the Batawana, split from another and relocated to the northwest in the early $19^{\text {th }}$ century (Gapa 2017; Tlou and Campbell 1997). The Batawana worked to subordinate and incorporate the Wayeyi under their political structures, with British protectorate policies of indirect rule eventually solidifying the Batawana chief's political and resource control over Wayeyi (Gapa 2017). Since its formation in 1995, a Wayeyi advocacy group, the Kamanakao Association, has prominently asserted the Wayeyi economic and social subjugation under the Batawana and advocated for the group's right to teach Shiyeyi language in schools and have their chief recognized at the same level as Tswana chiefs nationally (Nyati-Ramahobo 2006a; Nyati-Saleshando 2011).

Thato felt his Wayeyi ethnic identity most strongly in relation to his family home deep in the Delta, where he lived with his maternal grandmother as a child. Thato spoke of home with a mournful nostalgia:

I liked where I grew up, because everybody there speaks Shiyeyi, even the kids. You hear Setswana here and there, but most of the time they only speak Shiyeyi. That is the only ethnic group there. I enjoy being there, because we are able to preserve our culture so that it doesn't die. At school we learn that culture is dynamic, not static, but there, there is nothing like that. It feels like nothing is changing. 
He tried to impress upon us the magic of the place, saying you could lie in bed at night and hear the lions and elephants just outside the village. Botswana's government has also recognized value in the unparalleled nature of Thato's childhood home and has leased the area as private concessions for luxury safari operators. As a result, there are no schools there. Thato started school at age eight, as opposed to the more common five or six year starting age. Even then, he began school only at his mother's hard decision that it was worth his leaving home to become educated. His connection to the family village had faded since he left, and since his grandmother's passing three years prior. He described returning with his sister two years ago for the first time in many years: "After my grandmother died I hadn't gone there. Then I took time to go and just see [where I used to stay].”

In his school's village, where Thato had spent most of his time since leaving his grandmother's home, he found few opportunities to maintain and develop his Wayeyi identity. As a regional government administrative center with civil servants from throughout the country and residents from all of the region's ethnic groups, the village's lingua franca was Setswana. Although 50 percent of students in his school identified as Wayeyi, Thato believed himself to be the only student who spoke the Shiyeyi language. The experience of living in a predominantly Wayeyi village but hearing almost no Shiyeyi had instilled in him both a responsibility to maintain his Wayeyi culture and great value in his singularity as a Shiyeyi speaker among a generation widely believed to have lost the language. Although he lived with his sister, who worked in the government hospital in town, he preferred to spend as much time as possible with more distant relatives in the village, who could teach him "deep Shiyeyi language." As he said in an interview, "Shiyeyi, I speak it so that I cannot forget and to show that I belong to Wayeyi."

In line with a dual-identity model, Thato desired to develop his Wayeyi identity alongside, not to the exclusion of his national identity. Thato's national identity and the 
Setswana language served to connect him to fellow citizens as well as educational advancement and future employment. He felt his national identity most concretely in interactions at school. As he pointed out, Setswana "helps me to communicate with other people than Wayeyi, because it is not all Batswana [Botswana citizens] who can speak Shiyeyi." It was through his interactions in Setswana with teachers and students who had come to the school's village "on transfer" in civil servant posts that Thato learned about life in other parts of Botswana and felt connected to the larger nation-state. In a research club discussion about some students' tendency to separate into same-language groups on the school grounds, Thato advocated for using Setswana as a national language in these situations, reasoning, “there's no [way] you can learn about [each other's] cultures" when students separate and will not speak in a language that others can understand. Setswana, he suggested, could be the way to bring them together.

Yet, through such interactions with students and staff from other parts of Botswana, he also came to understand the marginal place that his home Northwest District and its ethnic groups occupied in the national imagination. He had heard that other regions "almost have everything [material resources] in schools compared to the schools here," which served to build his perception of existing horizontal inequalities. He also described his constant awareness of how ethnic groups from the Northwest District were treated as inferior by teachers, students, and community members from other regions, particularly if they spoke minority languages: "Sometimes when you speak your own language they look down on you, thinking that maybe you're inferior or you don't understand some things. You're still not advanced." Connecting back to this idea in a later interview, he reflected, "For [Tswana ethnic groups] when they speak Setswana it is their ethnic group language and also national language. It's like they have double language." Thato neither described an emotional connection to Tswana language and culture nor resentment of the expectation to adopt them. 
Yet he chafed under the knowledge he had gained from his own experiences that these bases of what he had been taught explicitly to believe was an inclusive national identity allowed citizens of Tswana ethnic groups to feel they were superior to others, including himself.

Although he associated Setswana language and culture with others' ethnic identity, Thato understood them as aspects of his national identity that were instrumental to his educational and career success, alongside English. He explained, "In school, we spend a lot of time speaking Setswana, and there is a Setswana subject. We don't have a Shiyeyi subject.” He further explained, "[My family] encouraged me before I started school that I should keep on speaking Setswana and English, because that is the only language that you are taught at school." Thato believed wholeheartedly in the importance of education for his future, and he took his family's advice. Although he found it difficult to express himself in English, often stuttering or pausing to search his mind for the word he meant, Thato practiced speaking English at every opportunity. Yet not all teachers recognized the hurdles that he had faced to access education and the unceasing effort with which he approached learning. The first time we observed a lesson with his class, Thato's hand shot up in response to every question from the teacher. The third time he spoke, he struggled to make a point in English about the moral implications of abortion. The teacher, growing impatient, told the class, "Maybe Thato is saying something, but we don't know what." Turning to Thato, he said, "You shouldn’t try to say something. I told you, if you want to say something you should just say it." Fully confident in his academic effort and abilities, despite such comments, Thato expected to earn a place at senior secondary school and beyond. In the previous year, around 65 percent of students in Botswana progressed from junior to senior secondary school, but in Thato's home Northwest District, only approximately 45 percent made this transition (Statistics Botswana 2014). Yet hearing teachers discuss the link between education and 
employment, and seeing the example of numerous aunts and uncles employed as civil servants, he expected that this education would lead to a job and security.

Thato was adept at navigating school expectations to speak English and Setswana and acted on the belief that his equal rights as a citizen would allow him to continue his education and find gainful employment. Yet, he imagined how his equality could be more fully realized if his school adopted a pluralistic model for building Botswana's national identity that would recognize his equality not just as an individual citizen, but also as a member of the Wayeyi group. In a focus group, he asserted that Botswana could follow the example of Namibia and South Africa by promoting multiple indigenous languages of instruction. When students in a research club discussion insisted that speaking minority languages prevented a person from communicating with a national or global community, Thato used his own experience to argue back, "How can we say that a person who speaks Shiyeyi cannot communicate with Americans? For example, me, I can speak Shiyeyi, but I can [also] communicate with an English [-speaking] person." In an interview, he explained that he knew about the lengthy advocacy campaign in which the Wayeyi had been petitioning to have their chief recognized in the national traditional leadership body, the Ntlo ya Dikgosi (House of Chiefs), ${ }^{2}$ yet this issue had never been discussed in his schools. While recognizing that "no country is 100 percent good," he argued that the government could do more to treat all ethnic groups equally. As Thato saw it, the quest for equality was not yet complete: "They try, but it's not enough."

\section{Identity Negotiation for Equal Access to Education and Employment}

The salience of national versus ethnic identity and the various ways of enacting these identities depends on one's belief in their membership in a group as well as the value and emotional attachment that an individual places on these identities. In the following sections, 
we first analyze how structures, curricular content, and relationships in their schools shaped Onalenna and Thato's interpretation of their membership in, value associated with, and emotional attachment to their ethnic and national identities. We then draw insights from these two exceptional students' experiences to understand how the Botswana education system's recategorization approach may be less effective than a dual-identity approach for building a national identity inclusive of students who identify with minority ethnic backgrounds.

Onalenna and Thato's experiences demonstrate that schools effectively convey to students of all ethnic groups their equal status as legal members of the nation in the eyes of the state. In terms of educational structures, both students were able, and indeed expected, to attend schools accessible to students of any ethnic group. In content, their social studies teachers taught them that all citizens of Botswana enjoy equal rights, regardless of ethnicity. Yet, within his school, Thato sometimes experienced his membership in the nation, as an individual who identified with the Wayeyi ethnic group, as inferior to Tswana individuals' membership. This became clear as he cited relations with peers and teachers in which they "look down on you, thinking that maybe you're inferior" when he spoke a minority language; educational content that failed to recognize his Shiyeyi language or knowledge he had gained outside of school about advocacy for Wayeyi rights; and educational structures that made his access to schools comparatively difficult by forcing him to learn in Setswana without secondlanguage supports and requiring him to leave his home village to enroll in school.

Both students attached instrumental value to their national identity, most notably through their mastery of Setswana and English and their legal equality as individual citizens. Their schools' curricular content and teachers' advice and examples demonstrated to them that national identification - including speaking Setswana, attending public school, and mastering national curriculum that emphasized unity and toleration - provided a path to higher education and employment. Through their teachers' advice, and supported by social 
capital in the form of relatives who had successfully completed school and gained employment, Onalenna and Thato came to believe that by embracing their identity as national citizens they would enjoy access to higher education and employment without discrimination on the basis of their ethnicity. Whereas Onalenna's home language was also the national language, Thato experienced first-hand the necessity of speaking Setswana only when he entered school, where it was the language of instruction, and while living in the school's village, where it acted as the lingua franca for residents who originated in all parts of Botswana. Communicating in Setswana in schools accessible to citizens of all ethnic groups allowed Thato to form relationships with and gain knowledge of individuals from other ethnic groups; yet the tendency for students to assimilate to Bakgatla norms at Onalenna's school denied her such an opportunity to expand her multicultural knowledge at school. Thato believed speaking Setswana and English was useful as a means to communicate with other national citizens but did not necessitate abandoning Shiyeyi. However, his school experiences taught him that he could only pursue knowledge of his ethnic language in private spaces.

Despite the instrumental values Onalenna and Thato attached to their national identities, they described a greater emotional attachment to their ethnic identity. Although both students gained most of their knowledge of elements of ethnic identities outside of school, Onalenna recognized large areas of overlap between her ethnic identity and the national identity constructed through school curriculum and language policies, as when she noted that the school's name and dominant language were taken from the Bakgatla group. Thato, on the other hand, described with great sadness aspects of his ethnic identity that he found completely absent from school. Moreover, Thato had to physically leave the land of his childhood and ancestors in order to attend school at all. It was with a heavy heart that he remembered the language, home, and family traditions he left behind in order to fully access 
the goods promised by his national identity. Yet his reasonable expectation that he would access higher levels of schooling and find gainful employment motivated Thato to sacrifice the emotional connection to his ethnic identity while attending school, as required by the recategorization model he encountered there.

\section{Conclusion}

Thato was not alone in feeling that the state space of his school asked him to sacrifice his ethnic identity in favor of a national identity. Students of minority backgrounds across all case study schools described structures, curricular content, and relationships in their schools that pressured them to speak only Setswana or English, stigmatized or discriminated against them when they identified with their ethnic group, did not accord recognition of their ethnic groups' contributions, languages, or history and, in many cases, forced them from their families and home villages, relocating as far as 200 kilometers away to attend school. Coe finds in Ghana that students, in feeling this kind of alienation in schools, "will try to protect themselves from disappointment by being less hopeful and enthusiastic, and a little more cynical and wary" (2005:188). Yet for Thato, meaningful membership as a valued individual member of the nation was feasible and worthy of some sacrifice. Accessibility of further education and future employment mediated the relationship between the salience of an

unrecognized minority ethnic identity largely excluded from the state space of the school, and his willingness to enact a national identity in the school context.

The mediating effect of school success for Thato calls into question the effectiveness of the recategorization approach to building an inclusive national identity for Botswana. It is unlikely that a homogenizing national identity built on Tswana culture and language, as presented in Botswana's government junior secondary schools, will succeed in taking precedence over ethnic identities, for the majority of students who identify with minority ethnic groups. Thato's school, like many in predominantly ethnic minority regions (Pansiri 
2008), achieves consistently low passing rates for students hoping to progress to senior secondary school. In each year between 2009-2011 (the most recent years with school level data publicly accessible), approximately 50 percent of students in Thato's school failed the JSS leaving exams with a grade of D or worse; whereas the national rate was around 25 percent. Most passing students did so with an overall C grade (40-46 percent each year), and not a single student earned a grade of A or merit in those three years. Onalenna's school, on the other hand, nearly matched the national average rates at each letter grade in all three years. The student surveys administered by the research clubs show that 86 percent of students in Onalenna's school self-identified as belonging to one of the Tswana ethnic groups; at Thato's school, Tswana students made up only 9 percent. Given disparities in JSS pass rates disproportionately disadvantaging students of ethnic minority backgrounds, students whose school experiences demonstrate that identifying with their ethnic group will exclude them from full membership in the nation, are, on average, also less likely to access the educational and employment outcomes promised by enacting a national identity.

Thato and Onalenna further reveal that students in Botswana's junior schools are accessing knowledge of campaigns for minority rights and recognition in their homes, media, and communities, despite their schools' silence on these issues. As public discourse increasingly highlights inequalities in recognition of ethnic groups, it seems likely that the public will begin to perceive disparities in educational achievement as horizontal inequalities between ethnic groups. Such belief in group-level inequalities has been shown to undermine social stability and predict the violent conflict that Botswana has so successfully averted to date (King 2014). The recategorization approach to management of national identity in Botswana emerged as a postcolonial project, focused on the redistribution of power and resources through unity and avoidance of conflict. Fifty years post-Independence, this same approach instead serves to entrench inequalities, rewarding those who relinquish claims to 
ethnic identity in favor of Tswana-normed national identity with educational and employment opportunities.

Yet the dual identity model provides some hope, reinforced by our and other empirical data in Botswana, that individuals can embrace both ethnic and national identities, even when the language, history, and cultural practices of these two social identities are distinct. Thato's willingness to embrace Setswana but desire to maintain Shiyeyi as an important aspect of his ethnic heritage echoes Cook's (2003) findings in research among minority KhoiSan groups, that they expressed a preference for speaking and learning Setswana when phrased as an either/or choice but for home language when phrased to offer the option of speaking both (as cited in Nyati-Ramahobo 2006b). Furthermore, Werbner (2002) argues that, in Botswana, those groups that have most actively sought recognition have done so out of a desire to redefine the national identity as heterogeneous, not to recede into an ethnic enclave or to secede from the nation. On our student research club surveys, 55 percent of students in Onalenna's and 57 percent at Thato's school report that they "feel equally Motswana and my ethnic group." From these students' perspectives, both social identities are relevant and not mutually exclusive for individuals.

Advocates for multilingual and multicultural education in Botswana have suggested that the education system could more fully include individuals who identify with minority ethnic groups by offering instruction in minority languages and recognizing historical perspectives and cultural practices of non-Tswana ethnic groups (see, for example, Boikhutso and Jotia 2013; Jotia and Pansiri 2013; Nyati-Saleshando 2011). Our findings further suggest that Botswana's education system could build an inclusive national identity that continues to focus on peace and unity while at the same time recognizes diverse ethnic identities within the nation, rather than laying seeds of future conflict through continued efforts to erase them. 


\section{Notes}

${ }^{1}$ Sesotho is the national language of nearby Lesotho and is mutually intelligible with Setswana.

${ }^{2}$ The Wayeyi are one of the numerous ethnic groups in Botswana that are not named in Botswana's Constitution. Only the chiefs of the eight named groups, the Tswana "major tribes," have the rank of "paramount chief" in the Ntlo ya Dikgosi, which has jurisdiction over any matter deemed to be "cultural" in Botswana. The Wayeyi tribe first took their case to Botswana's High Court in 1999 (Nyati-Ramahobo 2006b). After our fieldwork was completed, in May 2016, Government informed the Wayeyi that their paramount chief would be recognized in accordance with the 2008 Bogosi Act . 


\section{References}

Apple, Michael W. 2004 Ideology and curriculum. New York: RoutledgeFalmer.

Ashcraft, Catherine, Elizabeth K. Eger, and Kimberly A. Scott 2017 Becoming Technosocial Change Agents: Intersectionality and Culturally Responsive Pedagogies as Vital Resources for Increasing Girls' Participation in Computing. Anthropology and Education Quarterly 48(3):233-251.

Boikhutso, Keene, and Agreement Lathi Jotia 2013 Language identity and multicultural diversity in Botswana. International Boli, John Journal of Lifelong Education 32(6):797-815.

1989 New citizens for a new society : the institutional origins of mass schooling in Sweden. Oxford England; New York: Pergamon Press.

Chapman, Rebekah, et al.

2013 School-Based Programs for Increasing Connectedness and Reducing Risk Behavior: A Systematic Review. Pp. 95-114, Vol. 25. New York.

Coe, Cati

2005 Dilemmas of culture in African schools : youth, nationalism, and the transformation of knowledge. Chicago: University of Chicago Press.

Collins, Patricia Hill

2012 Social Inequality, Power, and Politics: Intersectionality and American Pragmatism in Dialogue. Pp. 442-457, Vol. 26: Pennsylvania State University Press.

Cornell, Stephen, and Douglas Hartmann 1998 Ethnicity and Race: Making Identities in a Changing World.

Dalley, Mahlon, et al.

2013 Definitions of Peace and Reconciliation in Africa. In International Handbook of Peace and Reconciliation. K. Malley-Morrison, A. Mercurio, and G. Twose, eds. Pp. 81-97. New York: Springer.

Davies, Lynn

2011 Can Education Interrupt Fragility? Towards the Resilient and Adaptable State. In Educating Children in Conflict Zones: Research, Policy, and Practice for Systemic Change (A Tribute to Jackie Kirk). K. Mundy and S. Dryden-Peterson, eds. Pp. 33-48. New York: Teachers College Press.

Davis, Christina P.

2015 Speaking Conflict: Ideological Barriers to Bilingual Policy Implementation in Civil War Sri Lanka. Anthropology \& Education Quarterly 46(2):95-112.

Dovidio, John F., et al.

2010 Recategorization and Prosocial Behavior: Common In-Group Identity and a Dual Identity. In The Psychology of Prosocial Behavior: Group Processes, Intergroup Relations, and Helping. S. Stürmer and M. Snyder, eds. Pp. 191-208. Chichester, UK: Wiley-Blackwell.

Dovidio, John F., Samuel L. Gaertner, and Kerry Kawakami

2003 Intergroup contact: The past, present, and the future. Group Processes \& Intergroup Relations 6(1):5-21.

Freedman, Sarah Warshauer, et al.

2008 Teaching History after Identity-Based Conflicts: The Rwanda Experience.

Comparative Education Review 52(4):663-690.

Gaertner, Samuel L., and John F. Dovidio 2000 Reducing intergroup bias : the common ingroup identity model. Philadelphia, PA: Psychology Press. 
Gapa, Angela

2017 Identity Management: The Creation of Resource Allocative Criteria in

Botswana. African Studies Quarterly 17(1):1-22.

Green, Andy

1990 Education and state formation : the rise of education systems in England, France, and the USA. New York: St. Martin's Press.

Gulbrandsen, Ørnulf

2012 The state and the social : state formation in Botswana and its pre-colonial and colonial genealogies. New York: Berghahn Books.

Gurr, Ted Robert

1970 Why men rebel. Princeton, N.J.,: Published for the Center of International

Studies, Princeton University by Princeton University Press.

Gutmann, Amy

1999 Democratic education. Princeton, N.J.: Princeton University Press.

Han, Huamei

2014 Westerners,' 'Chinese,' and/or 'Us': Exploring the Intersections of Language,

Race, Religion, and Immigrantization. Anthropology and Education Quarterly 45(1):54-70.

Janson, Tore, and Joseph Tsonope

1991 Birth of a national language : the history of Setswana. Gaborone, Botswana:

Heinemann Botswana : National Institute of Development Research and Documentation.

Jotia, Agreement, and Nkobi Owen Pansiri

2013 Multicultural Education: The Missing Link in Botswana Education Policy.

European Journal of Educational Studies 5(1):101-110.

King, Elisabeth

2014 From classrooms to conflict in Rwanda. New York: Cambridge University Press.

Kymlicka, Will, and W. J. Norman

2000 Citizenship in diverse societies: Issues, Contexts, Concepts. In Citizenship in diverse societies. W.J. Norman and W. Kymlicka, eds. Pp. 1-41, Vol. Book, Whole. Oxford ;New York: Oxford University Press.

Lawrence-Lightfoot, Sara, and Jessica Hoffmann Davis

1997 The Art and Science of Portraiture. San Francisco: Jossey-Bass.

Lee, Jin Sook, and Debra Suarez

2009 A Synthesis of the Roles of Heritage Languages in the Lives of Children of Immigrants: What Educators Need to Know. Bristol, England.

Lerch, Julia C., S. Garnett Russell, and Francisco O. Ramirez

2017 Wither the Nation-State? A Comparative Analysis of Nationalism in

Textbooks. Social Forces 96(1):153-180.

Marope, P. T. M.

1996 The impact of educational policy reforms on the distribution of educational outcomes in developing countries: The case of Botswana. International Journal of Educational Development 16(2):157-171.

Michalopoulos, Stelios, and Elias Papaioannou

2015 On the ethnic origins of African development: Chiefs and precolonial political centralization. The Academy of Management Perspectives 29(1):32-71.

Nader, Laura

1997 Controlling Processes: Tracing the Dynamic Components of Power. Current Anthropology 38(5):711-738. 
Nyati-Ramahobo, Lydia

2006a Language policy, cultural rights and the law in Botswana. Contributions to the Sociology of Language 92(285-304).

2006b The long road to multilingual schools in Botswana. In Imagining multilingual schools: Languages in education and glocalization. O. Garcia, T. Skutnabb-Kangas, and M.E. Torres-Guzman, eds. Pp. 200-222. Linguistic Diversity and Language Rights, Vol. 2. Tonawanda, NY: Multilingual Matters, Ltd.

Nyati-Saleshando, Lydia

2011 An Advocacy Project for Multicultural Education: The Case of the Shiyeyi Language in Botswana. International Review of Education 57(5-6):567-582.

Østby, Gudrun, and Henrik Urdal

2010 Education and Civil Conflict: A Review of the Quantitative Empirical Literature. UNESCO.

Osterman, Karen F.

2000 Students' Need for Belonging in the School Community. Review of Educational Research 70(3):323-367.

Paniagua, Alejandro

2017 The Intersection of Cultural Diversity and Special Education in Catalonia: The Subtle Production of Exclusion through Classroom Routines. Anthropology and Education Quarterly 48(2):141-158.

Pansiri, Nkobi Owen

2008 Improving commitment to basic education for the minorities in Botswana: A challenge for policy and practice. International Journal of Educational Development 28(4):446-459.

Paulson, Julia

2015 "Whether and How?" History Education about Recent and Ongoing Conflict:

A Review of Reseach. Journal on Education in Emergencies 1(1):14-47.

Presidential Task Group for a Long-Term Vision for Botswana

1997 Vision 2016: Long-Term Vision for Botswana, Towards Prosperity For all.

Gaborone: Government Printing and Publishing Services.

Republic of Botswana

1977 Education for kagisano: Report of the national commission on education.

Gaborone: Government Printer.

2000 Report of the Presidential Commission of Inquiry into Sections 77, 78, and 79 of the Constitution of Botswana. Government Printer.

Ríos-Rojas, Anne

2014 Managing and Disciplining Diversity: The Politics of Conditional Belonging in a Catalonian Institut. Anthropology \& Education Quarterly 45(1):2-21.

Robinson, Amanda Lea

2009 National Versus Ethnic Identity in Africa: State, Group, and Individual Level

Correlates of National Identification. Afrobarometer.

Ross, Marc Howard

2007 Cultural contestation in ethnic conflict. Cambridge: Cambridge University

Press.

Segokgo, Bakang

2016 Wayeyi Recognised Tribe. Botswana Daily News, 29 May 2016.

Selander, S. 
1990 Towards a theory of pedagogic text analysis. Scandinavian Journal of Educational Research 34(2):143-150.

Shin, Sarah J.

2013 Bilingualism in schools and society : language, identity, and policy. New

York.

Smith, Anthony D.

1991 National identity. Reno: University of Nevada Press.

Statistics Botswana

2014 Secondary Education Statistics Brief 2014. Gaborone, Botswana: Statistics Botswana.

Sumi, Cho, Kimberlé Williams Crenshaw, and Leslie McCall

2013 Toward a Field of Intersectionality Studies: Theory, Applications, and Praxis.

Signs: Journal of Women in Culture \& Society 38(4):785-810.

Tabulawa, Richard

2009 Education reform in Botswana: Reflections on policy contradictions and paradoxes. Comparative Education 45(1):87-107.

Tajfel, Henri

1982 Social psychology of intergroup relations. Annual Review of Psychology 33:1-39.

Tajfel, Henri, and John C. Turner

1979 An integrative theory of intergroup conflict. In The social psychology of intergroup relations. W.G. Austin and S. Worchel, eds. Pp. 33-48. Monterey: CA: Brooks/Cole.

Teeger, Chana

2015 "Both Sides of the Story": History Education in Post-Apartheid South Africa. American Sociological Review 80(6):1175-1200.

Tlou, Thomas, and Alec C. Campbell

1997 History of Botswana. Gaborone, Botswana: Macmillan Botswana.

UNESCO

2011 Education for All Global Monitoring Report 2011: The hidden crisis: Armed conflict and education. UNESCO.

Uslaner, Eric M., and Bo Rothstein

2012 The Roots of Corruption: Mass Education, Economic Inequality and State Building. Conference Papers -- American Political Science Association, 2012, pp. 145.

Vail, Leroy

1989 Ethnicity in Southern African History. In The Creation of tribalism in Southern Africa. L. Vail, ed. Pp. 1-. London; Berkeley: Currey; University of California Press.

van Oudenhoven, Jan Pieter, Karin S. Prins, and Bram P. Buunk 1998 Attitudes of Minority and Majority Members towards Adaptation of Immigrants. European Journal of Social Psychology 28:995-1013.

Weber, Eugen Joseph

1976 Peasants into Frenchmen : the modernization of rural France, 1870-1914.

Stanford, Calif.: Stanford University Press.

Werbner, Richard P.

2002 Challenging Minorities, Difference and Tribal Citizenship in Botswana. Journal of Southern African Studies 28(4):671-684. 
2004 Reasonable radicals and citizenship in Botswana : the public anthropology of Kalanga elites. Bloomington: Indiana University Press. 